\title{
SWARD STRUCTURE AND HERBAGE YIELD OF ROTATIONALLY STOCKED PASTURES OF 'Marandu' PALISADEGRASS [Brachiaria brizantha (A.Rich.) Stapf] AS AFFECTED BY HERBAGE ALLOWANCE
}

\author{
Gustavo José Braga ${ }^{1}$; Carlos Guilherme Silveira Pedreira ${ }^{2 *}$; Valdo Rodrigues Herling ${ }^{3}$; Pedro \\ Henrique de Cerqueira Luz ${ }^{3}$; César Gonçalves de Lima ${ }^{4}$ \\ ${ }^{I}$ APTA Regional Centro-Oeste, R. Sebastião Soares s/n - 17380-000 - Brotas, SP - Brasil. \\ ${ }^{2}$ USP/ESALQ - Depto. de Zootecnia, C.P. 09 - 13418-900 - Piracicaba, SP - Brasil. \\ ${ }^{3}$ USP/FZEA - Depto. de Zootecnia, Av. Duque de Caxias Norte, 225 - 13535-900 - Pirassununga, SP - Brasil. \\ ${ }^{4}$ USP/FZEA - Depto. de Ciências Básicas. \\ *Corresponding author <cgspedre@esalq.usp.br>
}

ABSTRACT: In ruminant-forage systems herbage allowance (HAL) has a major impact on grazing intensity and sward structure, affecting animals, plants, and ultimately, pasture yield. Data on HAL responses of tropical cultivated pastures are scarce and this information may be useful in optimizing pasture utilization. The objective of this study was to describe and contrast sward structure and herbage accumulation responses of 'Marandu' palisadegrass [Brachiaria brizantha (A.Rich.) Stapf] pastures to HAL during two grazing seasons (warm-rainy season of 2003 and 2004). Treatments were four daily HAL levels, 5, 10, 15 and 20 $\mathrm{kg}$ herbage mass per $100 \mathrm{~kg}$ live weight (\%) in a rotational stocking system with 35 days of grazing cycle (28-day rest; 7-d grazing). Post-graze swards were shorter $(\sim 17 \mathrm{~cm})$ under 5\% HAL. For the other HAL levels, postgraze sward height increased throughout the experiment $(21$ to $50 \mathrm{~cm})$. Changes in sward light interception (LI) were highly associated with height, but differed across HALs in 2004. Early in the 2003 season, HAL increases resulted in linear increase of the daily herbage accumulation rate (HAR; 47, 66, 78, and $98 \mathrm{~kg} \mathrm{DM} \mathrm{ha}^{-1} \mathrm{~d}^{-1}$ for $5,10,15$ and $20 \%$-HAL, respectively). For the subsequent grazing cycles of 2003 and all through 2004, HAR decreased with increasing HAL. This was associated with the excessive increase in sward height and mean forage mass, caused by lower grazing intensity. The use of lax (high) HAL to maximize animal performance, especially 10, 15 and 20\%-HAL, resulted in decreased pasture performance (lower herbage accumulation, HAC) in palisadegrass pastures.

Key words: herbage accumulation, sward height, light interception, forage mass

\section{ESTRUTURA DO DOSSEL E PRODUÇÃO DE FORRAGEM EM PASTAGENS DE CAPIM MARANDU [Brachiaria brizantha (A.Rich.) Stapf] SOB LOTAÇÃO ROTACIONADA EM RESPOSTA À OFERTA DE FORRAGEM}

RESUMO: A oferta de forragem (OF) aos animais em pastejo causa forte impacto na intensidade de desfolhação e conseqüentemente na estrutura do dossel, influindo indiretamente no acúmulo de forragem. O objetivo deste estudo foi avaliar estrutura do dossel e acúmulo de forragem em pastagens de capimMarandu em resposta à OF. Os tratamentos foram quatro OFs, 5, 10, 15 e $20 \mathrm{~kg}$ massa de forragem por 100 $\mathrm{kg}$ peso vivo por dia (\%), em ciclos de pastejo de 35 dias ( $28 \mathrm{~d}$ de descanso e $7 \mathrm{~d}$ de ocupação). A altura do dossel no pós-pastejo foi mais baixa para a OF $5 \%$, que se manteve em torno de $17 \mathrm{~cm}$, enquanto que para as demais houve aumento progressivo dos valores ao longo do experimento (21 a $50 \mathrm{~cm})$. A variação na interceptação de luz (IL) em função da altura do dossel foi significativa, e em 2004 diferiu entre OFs. Inicialmente o aumento da OF resultou em aumento linear da taxa diária de acúmulo de forragem (TAF), com 47, 66, 78 e $98 \mathrm{~kg}$ forragem ha ${ }^{-1}$ (ciclo I-2003), nas pastagens sob OF 5, 10, 15 e 20\%, respectivamente. Entretanto, nas rebrotações posteriores houve diminuição acentuada da TAF para OFs mais elevadas, condição que persistiu no segundo ano do experimento (2004), e foi associada ao excessivo aumento da altura do dossel e da massa de forragem, como conseqüência da diminuição da intensidade de pastejo. A utilização de OFs generosas com intuito de elevar o desempenho animal, trouxe conseqüências negativas sobre o acúmulo de forragem em pastagens de capim Marandu.

Palavras-chave: acúmulo de forragem, altura do dossel, interceptação de luz, massa de forragem 


\section{INTRODUCTION}

Palisadegrass is one of the most cultivated forage grasses in Central Brazil, due mainly to spittlebug (Deois sp. and Notozulia entreriana) resistance and high yield potential. In the Zona da Mata of the state of Pernambuco, Northeastern Brazil, the total herbage accumulation in palisadegrass pastures can reach 28 $\mathrm{Mg} \mathrm{DM} \mathrm{ha}{ }^{-1}$ during the rainy season (Santos et al., 2003 ). About 10.5 million ha (21\% of total improved grasslands area) are cultivated with palisadegrass in Central Brazil (Macedo, 2004), supporting 56 million head of cattle (Bos spp.) (Vilela et al., 2004). Released by EMBRAPA in 1984 (Nunes, 1984), 'Marandu' palisadegrass currently ranks first in the Brazilian forage seed market: $44 \%$ of the total amount of seed commercialized (Valle et al., 2004).

Grazing systems profitability depends not only on herbage yield, but also on the efficiency with which produced herbage is harvested by the grazing animal. Both yield and efficiency result, among other factors, from the choice of defoliation strategies that are ultimately devised with animal performance and animal productivity goals in mind (Pedreira et al., 2005; Teixeira et al., 1999). Herbage allowance (HAL) has a major impact on herbage intake and animal performance in grazing systems (Boval et al., 2000). In addition, when used to establish defoliation strategy guidelines, HAL affects plant regrowth potential as a result of its effect on sward structure and plant morphology (Kim et al., 2001). Increasing HAL as a management strategy to maximize animal performance, reduces grazing intensity, leading to continued decline in forage nutritive value and grazing efficiency. Reducing HAL, on the other hand, increases grazing intensity and maximizes animal gain per unit area, and can reduce herbage accumulation in extreme situations (Virkajärvi et al., 2002). Adjei et al. (1980) reported, however, that in Cynodon spp. pastures under intermittent grazing with rest periods of 28-days, forage yield was higher for the 4\%-HAL treatment (kg herbage mass $100 \mathrm{~kg}$ live weight ${ }^{-1}$ day $^{-1}$ ) when compared to 6$11 \%$.

Dependence of plant regrowth vigor on residual leaf area and light interception (LI) immediately after defoliation has long been established (Humphreys, 1991). In steady-state stands, such as in continuously stocked pastures, the role of sward structure as it relates to canopy LI and to leaf area index (LAI) is recognized as key in establishing cause-effect relationships involving agronomic responses to management (Parsons et al., 1983). It is not clear, however, whether these associations hold true in swards under intermittent defoliation, as the dynamics of successive cycles of defoliation followed by regrowth make for a wide range of sward conditions over short periods of time. It is uncertain, for example, whether LAI and LI can be accurately estimated by measurements of sward height in intermittently grazed swards (Parsons et al., 1988). The diverse conditions of sward structure produced by manipulation of HAL and regrowth period can help identify relationships between sward height and LI that support new management guidelines for palisadegrass under intermittent grazing. The objective of this study was to evaluate the effects of HAL on herbage accumulation and its relation with selected sward structure descriptors in palisadegrass pastures under rotational stocking.

\section{MATERIAL AND METHODS}

The study was conducted in Pirassununga, São Paulo, Brazil (21 ${ }^{\circ} 59^{\prime} \mathrm{S}, 47^{\circ} 26^{\prime} \mathrm{W}$; altitude $634 \mathrm{~m}$ ) during two years (grazing seasons). Monthly rainfall and daily mean temperature during experimental period (Figure 1) were recorded at the Air Force Academy (AFA) $15 \mathrm{~km}$ from the experimental site.

A palisadegrass pasture, established in 1997, was used in this study. The soil at the experimental site was a Typic Hapludox with $\mathrm{pH}\left(\mathrm{CaCl}_{2}\right) 5.3$ and $\mathrm{P}_{\text {resin }}$ $8.7 \mathrm{mg} \mathrm{dm}^{-3}$. Concentrations of $\mathrm{K}, \mathrm{Ca}$ and $\mathrm{Mg}$ were 1.3 , 23 and $10-\mathrm{mmol}_{\mathrm{c}} \mathrm{dm}^{-3}$, respectively. The pasture was limed in Nov. 2001 with $0.7 \mathrm{Mg} \mathrm{ha}^{-1}$ of dolomitic lime applied to the soil surface. In the first year of the study, grazing commenced in Dec. 2002 and ended in March 2003 (105 d), and lasted from Jan. through April (105 d) in 2004, thereafter referred to as 2003 and 2004 seasons, respectively. Fertilization during the experimental period each year consisted of topdress applications of urea and potassium chloride totalizing $150 \mathrm{~kg} \mathrm{~N}$ and $63 \mathrm{~kg} \mathrm{~K} \mathrm{ha}^{-1}$, split in three postgraze applications.

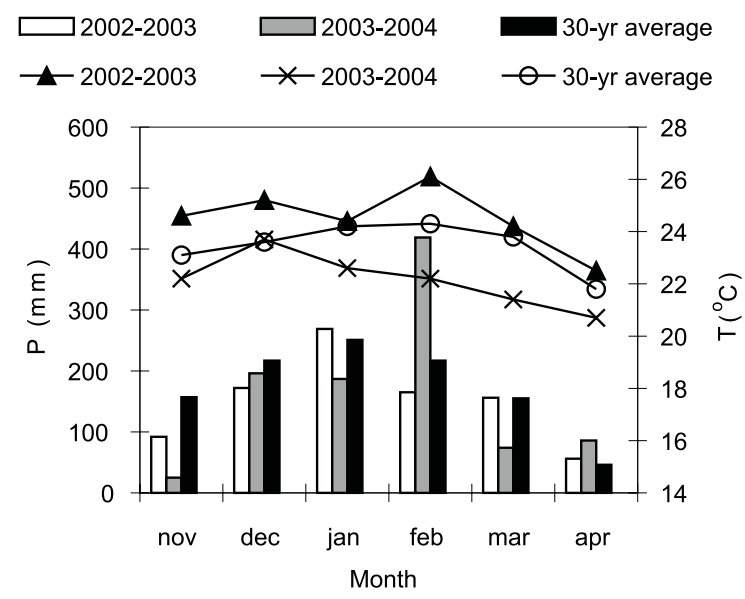

Figure 1 - Rainfall (P, bars) and daily mean temperature ( $\mathrm{T}$, lines) in Pirassununga, Brazil during the experimental period and $30-$ yr average 
Simple superphosphate $\left(18 \% \mathrm{P}_{2} \mathrm{O}_{5}\right)$ was applied at 39 $\mathrm{kg} \mathrm{P} \mathrm{ha}{ }^{-1}$ in Oct. 2002 after harvesting the forage mechanically at $20 \mathrm{~cm}$, and again in Dec. 2003 after the first grazing of the second year in each experimental unit.

Treatments were arranged in a randomized complete block design with four replications. A total of 25.5 ha were divided in 16 experimental units of 1.6 ha, each subdivided into five paddocks $(35 \times 90$ $\mathrm{m})$. Four levels of daily herbage allowance (HAL) were studied in a rotational stocking grazing method: 5,10 , 15 and $20 \mathrm{~kg}$ of forage dry matter (DM) per $100 \mathrm{~kg}$ animal liveweight (\%), using a 35 -d grazing cycle (7 $\mathrm{d}$ grazing and $28 \mathrm{~d}$ rest). Allowance levels were controlled in one of the five paddocks (control paddock) of each experimental unit and applied according to equation (1):

$$
\mathrm{HAL}=\mathrm{HM}_{\text {pre-graze }}\left[\left(\mathrm{LW} 100^{-1}\right) \times \mathrm{DG}\right]^{-1}
$$

where: $\mathrm{HAL}=$ herbage allowance $(\mathrm{kg}$ DM per $100 \mathrm{~kg}$ $\mathrm{LW}$ per day, \%); $\mathrm{HM}_{\text {pre-graze }}=$ herbage mass before grazing $\left(\mathrm{kg} \mathrm{ha}^{-1}\right) ; \mathrm{LW}=$ total animal liveweight (stocking density, $\mathrm{kg} \mathrm{ha}^{-1}$ )

Allowance values were later recalculated so as to establish an equivalence between HAL levels applied as treatments and HAL levels according to the "Forage and Grassland Terminology Committee" (FGTC, 1992). For that purpose, the procedure described by Sollenberger et al. (2005) was followed. The stocking rate during entire grazing cycle in the entire experimental unit (five paddocks) was considered, according to equation (2):

$$
\mathrm{HAL}=\left(\mathrm{HM}_{\text {mean }}\right)(\mathrm{kg} \mathrm{LW})^{-1}
$$

where, HAL = herbage allowance ( $\mathrm{kg}$ DM per $\mathrm{kg} \mathrm{LW})$; $\mathrm{HM}_{\text {mean }}=$ mean $\mathrm{HM}\left(\mathrm{kg} \mathrm{DM} \mathrm{ha}{ }^{-1}\right)$ calculated as [(pregraze + post-graze)/2]; LW = liveweight (stocking rate, kg LW ha ${ }^{-1}$ )

Animals were yearling Nelore (Bos taurus indicus L.) heifers with initial live weight of $250 \pm 10$ $\mathrm{kg}($ mean $\pm \mathrm{SD})$, and an average 15 months of age. In each experimental unit, four testers in 2003 and three in 2004, were used for assessing animal performance. Water and a mineral mix were offered ad libitum during the experimental period. "Put-and-take" animals were added or removed according to stocking density adjustments needed to reach a particular level of HAL, each grazing cycle in the control paddock. Animal shrunk weights (16 h without feed and water) were recorded every 35 days.

In 2003 pre- and post-graze HM were measured destructively in the control paddock by clipping the forage inside three quadrats $(1 \times 1 \mathrm{~m})$ at soil level, from sites that represented the mean HM of the paddock, through visual appraisal. In 2004, pre- and postgraze HM in the control paddock were estimated each cycle using double sampling and rising plate meter readings as the indirect measure (50 per paddock). Plate readings were calibrated against actual HM values during the course of the experiment, both at pre- and post-graze at five stations, which were double-sampled $(1 \times 1 \mathrm{~m})$ every sampling event. Double sampling stations were chosen so as to cover that range of lowest to highest HM in the paddock, through visual appraisal.

Together with HM measurements, mean sward height was estimated from 30 measurements in the control paddock at both pre- and post-graze, plus on the $14^{\text {th }}$ day (midpoint) of regrowth. For this purpose, individual readings were taken at the highest point reached by leaves and/or stems, avoiding disturbance in the sward. Light interception (LI) by the canopy was measured in each rest period, pre- and postgraze, plus on the $14^{\text {th }}$ day of regrowth, using a LAI-2000 canopy analyzer (Li-Cor, Lincoln, Nebraska, USA) at 15 sites in the control paddock. Mean daily herbage accumulation rate (HAR) was calculated by dividing herbage accumulation (HAC) during a rest period by 28 . From April to December 2003, pastures remained under the same HAL treatments used in the rainy season, except that the rest period was doubled to 56 days, keeping the same 7 days of grazing. During the dry season pastures received no fertilization and were only sampled for HM.

Data were analyzed using the MIXED and GLM procedures of SAS (SAS, 1999; Littell et al., 1996) for analysis of variance and regression analysis, respectively. Because the grazing seasons did not comprise the exact same time period in each of the two years, analysis of variance was run by year. In the mixed models analysis, block, HAL and grazing cycle were considered fixed effects. Within year, grazing cycle was considered a repeated measure in time because it could not be randomized. Responses to HAL were compared using orthogonal polynomial coefficients.

\section{RESULTS AND DISCUSSION}

Compared to the 30-yr average for the location of the experiment, the mean air temperature from Nov. to Apr. was higher $\left(\sim 1^{\circ} \mathrm{C}\right)$ in 2003 and lower in 2004 (Figure 1). Monthly rainfall was consistent with the 30-yr average, except for Feb. 2004, wetter than normal.

Mean HAL values during the grazing periods in control paddocks, calculated according to the 
method proposed by Sollenberger et al. (2005) were 1.5 ( \pm 0.03$), 3.1( \pm 0.07), 4.8( \pm 0.09)$, and $6.4( \pm 0.10)$ $\mathrm{kg}$ DM per $\mathrm{kg} \mathrm{LW}$, for the 5, 10, 15 and $20 \%$ treatments, respectively. These values cover a broad range of stocking rate and sward conditions, including the $3.3 \mathrm{~kg}$ DM per $\mathrm{kg}$ LW reported by McCartor \& Rouquette Jr. (1977) for pearl millet [Pennisetum glaucum (L.) R. Br.] as the threshold value below which animal performance is dependent on HAL. Still to be acclaimed by widespread use, the method of Sollenberger et al. (2005) not only respects the definition of HAL (FGTC, 1992) but also allows for the comparison of results from experiments using different stocking methods by means of a logical and rational procedure. For simplicity sake, however, data from the present study are presented and discussed using the HAL levels as applied as treatments 5, 10, 15 and 20\%.

There was a HAL $\times$ grazing cycle interaction on postgraze HM (Figure 2A) both in 2003 $(P<0.0001)$ and $2004(P<0.0001)$. The effect of HA on HM in 2003 was linear in cycles I and II, whereas on cycle III both linear and cubic coefficients were significant. In 2004, both the linear and the quadratic coefficients were significant for the effect of HAL on postgraze HM in all three cycles. The shape of the response relates to the fact that the increase in postgraze HM from 15 to $20 \%$ HAL was consistently lower in magnitude when compared to those from 5 to $10 \%$ and from 10 to $15 \%$ HAL. Pregraze HM was also affected by the HAL $\times$ cycle interaction in $2003(P<0.0001)$ and $2004(P=0.0041)$. Pregraze HM increased linearly with increased HAL in all cycles in 2003 (Figure 2B) as well as in the first grazing cycle of 2004, but for the second and third cycles of 2004 there was also a quadratic effect. Under 5\% HAL, pregraze HM was relatively constant throughout the experiment, in contrast with the other HAL levels. Mean postgraze HM was $2650 \mathrm{~kg} \mathrm{DM} \mathrm{ha}{ }^{-1}$ and mean pregraze HM was $4070 \mathrm{~kg} \mathrm{ha}^{-1}$. The increase in postgraze HM as the trial progressed was associated with the reduced grazing intensity in the higher HAL treatments.

Postgraze sward height was affected by the HAL $\times$ grazing cycle interaction, both in 2003 $(P<0.0001)$ and $2004(P=0.0267)$. In 2003, postgraze sward height for the 10,15 , and $20 \%$ treatments increased as the season progressed, in contrast with the 5\%-HAL treatment, where it remained around $17 \mathrm{~cm}$ (Figure 3A). A similar trend was observed in 2004, more noticeably for 15 and 20\% HAL, whereas for the 5\% treatment sward height was less variable, similar to that of 2003. The postgraze sward height response to HAL was positive and linear in all three grazing cycles of 2003, but both linear and quadratic coefficients were significant in 2004 (Figure 3B). At pregraze, sward height also was affected by the HAL $\times$ grazing cycle interaction in $2003(P<0.0001)$ and $2004(P=0.0298)$. Much like postgraze, pregraze sward height under 10, 15 and 20\% HAL was variable during the experimental period, especially in 2003. The effect of HAL on pregraze sward height was linear in 2003, and linear and quadratic in 2004. In mid-to-late rainy season, around February (second cycle in 2003 and first cycle in 2004) palisadegrass turned reproductive, with the emergence of seedheads, except on pas-
A

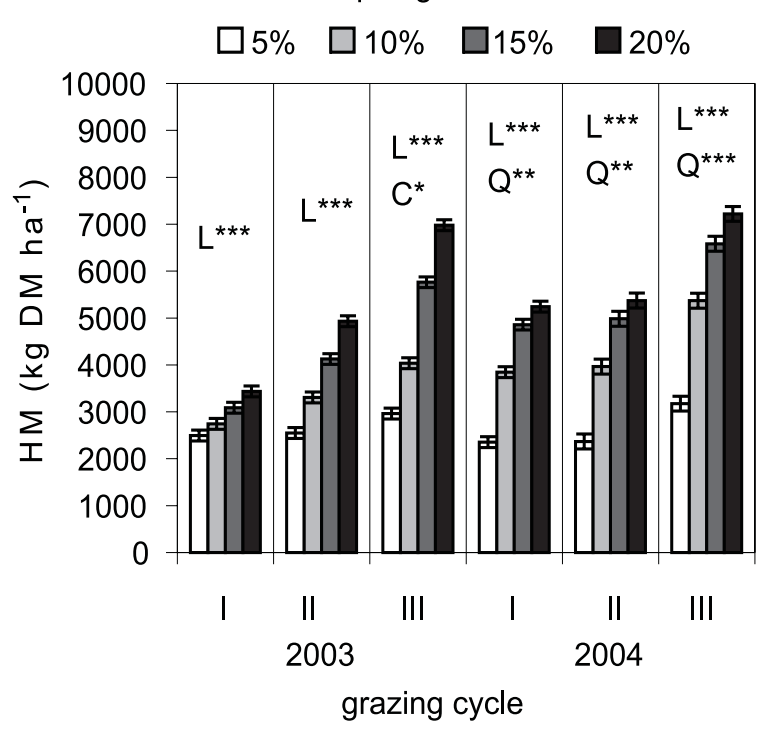

B

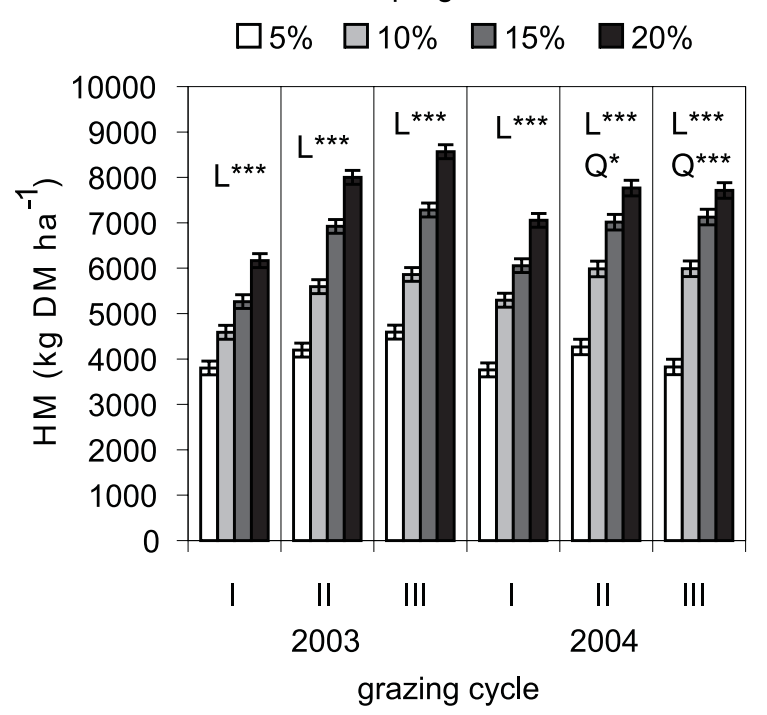

Figure 2 - Herbage mass (HM) on palisadegrass pastures at post-graze (A) and pre-graze (B) during three periods in 2003 and 2004 in response to herbage allowance (HAL; 5, 10, 15, 20\%). Atop each HAL bar are mean standard error (MSE) bars (I). The orthogonal polynomial coefficients refer to HAL effect: L linear, Q quadratic, C cubic. ${ }^{* * *} P<0.001, * * P<0.01, * P<0.05$. 
A

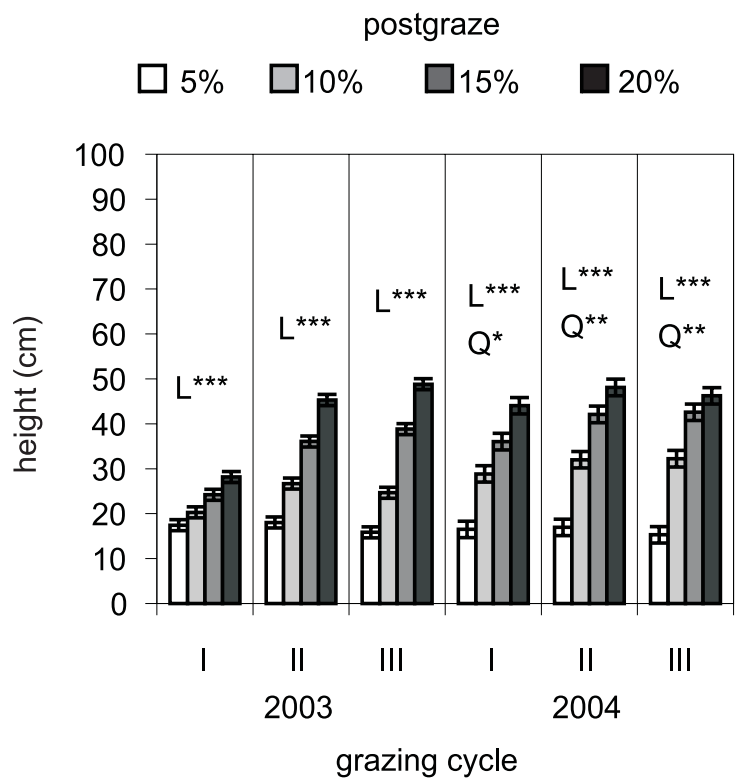

B

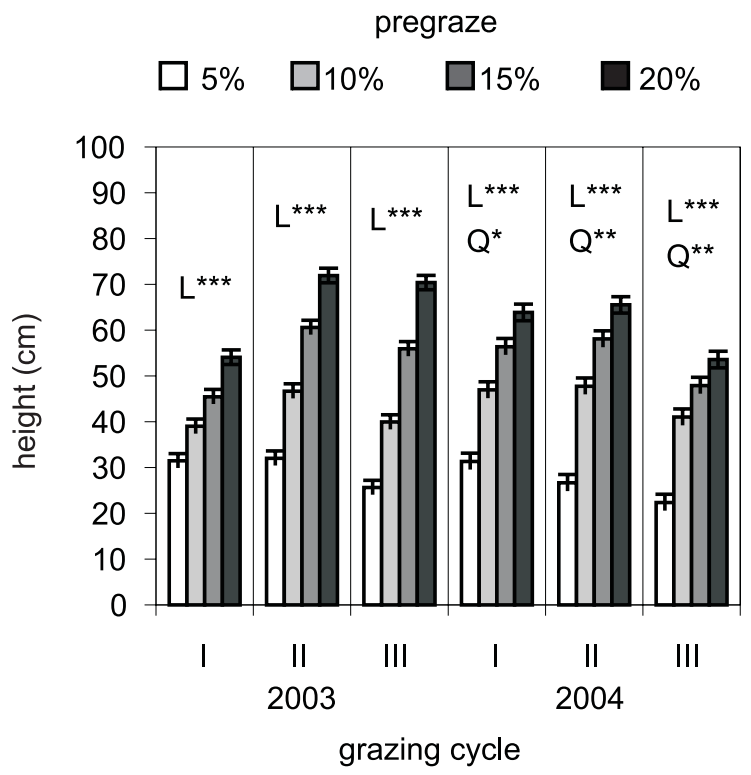

Figure 3 - Mean sward height in palisadegrass pastures in the post-grazing (A) and pre-grazing (B) during three periods in 2003 and 2004 in response to herbage allowance (HAL; 5, 10, 15, 20\%). Atop each HAL bar are mean standard error (MSE) bars (I). The orthogonal polynomial coefficients refer to HAL effect: L linear, Q quadratic effect, C cubic. $* * * P<0.001, * * P<0.01$, $* P<0.05$.

tures under 5\%-HAL, which sustained pregraze sward height at similar levels to those at first grazing in Dec. $2002(34 \mathrm{~cm})$. The inflorescence contributed to the increase in sward height on pastures under with 15 and $20 \%$ HAL, mainly due to stem elongation. This was more evident in 2003, probably because in 2004 the pastures responded to the grazing regime used in the previous dry season (latter part of 2003) when they were not harvested mechanically, something that was done prior to the beginning of the experiment in 2002. The linear effect of HAL on sward height has been reported for temperate grass pastures (Virkajärvi et al., 2002), but for most tropical species intense stem elongation seems to be the central issue if timing of defoliation is to be addressed. In dwarf elephantgrass (Pennisetum purpureum Schum. cv. Mott) pastures under continuous stocking, Almeida et al. (2000) found a linear response of sward height to daily HAL levels varying from 4 to $14 \%$ ( $\mathrm{kg}$ green $\mathrm{HM}$ per $100 \mathrm{~kg}$ liveweight).

In the present study, the increase in sward height was associated with increased sward light interception, LI (Figure 4), which relates to crop canopy height by a negative exponential, and this has been shown in tropical forage grasses (Mello \& Pedreira, 2004). Thus, the taller the sward, the smaller the fraction of total incoming radiation that reaches the soil surface, but only up to a point where increasing sward height no longer results in increased LI. For grazed palisadegrass, the relationship between sward height and the natural logarithm $(\mathrm{ln})$ of the radiation fraction that reached the soil surface (I/Io) was linear ( $\mathrm{y}=a+$ $b \mathrm{x})(P<0.0001)$, with $\mathrm{R}^{2}$-values ranging from 0.48 to 0.83 across HAL treatments and years (Figure 4$)$. In 2003 , the slope $(b)$ was similar $(P=0.4994)$ among HAL levels, but not in 2004, when the slope was higher $(P=0.0354)$ for 5 and 10\% HAL. From 2003 to 2004 , the slopes increased in the most intensively grazed pastures (5 and 10\% HAL), where swards produced prostrate plants. The prostrate growth habit makes it difficult for the grazing animal to prehend the forage, which in turn favors a higher residual leaf area and subsequent regrowth (Lemaire, 2001). In intermittently grazed Tanzania guineagrass (Panicum maximum Jacq.) pastures, Mello \& Pedreira (2004) found a single relationship between sward height and LI across grazing intensities and seasons of the year.

The sward height at which $95 \%$ of the light was intercepted differed across HALs and years. In 2003 these heights were $59,49,49$, and $50 \mathrm{~cm}$, and in 2004 they were $30,37,41$ and $47 \mathrm{~cm}$, respectively for $5,10,15$ and $20 \%$ HALs. The magnitude of the difference between years was higher for the lower HAL levels. In 2003, the range of LI values used to generate the 5\%-HAL model, did not include LI values equal to or higher than $95 \%$, which probably resulted in a higher error of the estimate. Reproductive swards in the high HAL treatments probably increased the error deviation of the regression model of sward height and LI, and this can be partially explained by stem elongation, as emphasized by Korte et al. (1982). Even for $5 \%$-HAL, however, where stem elongation was almost 
2003
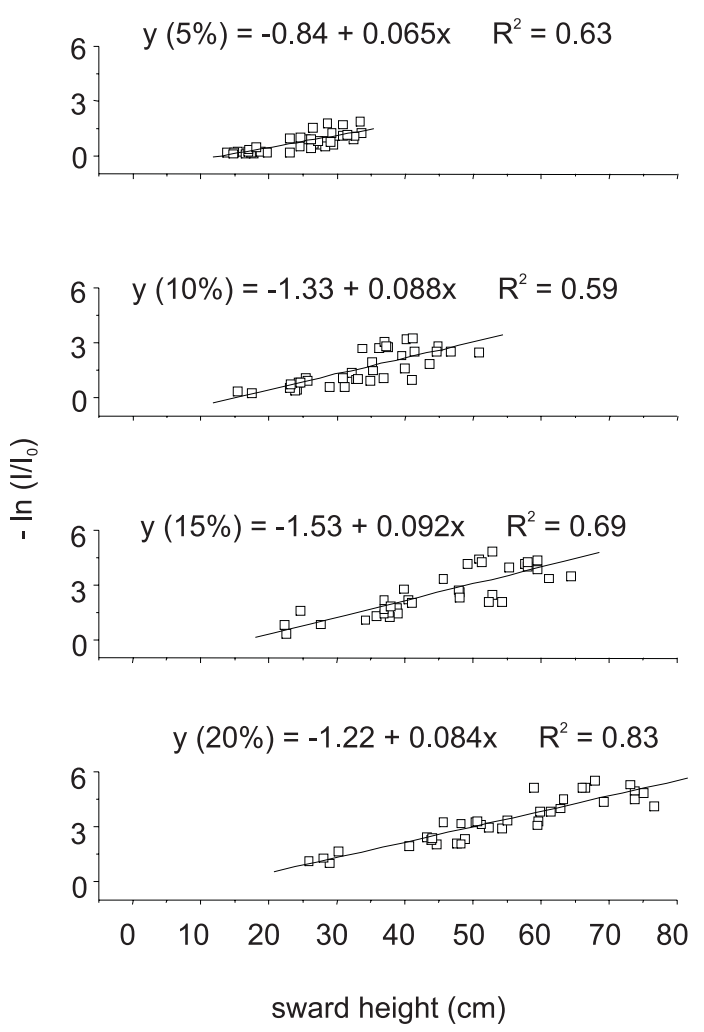

2004
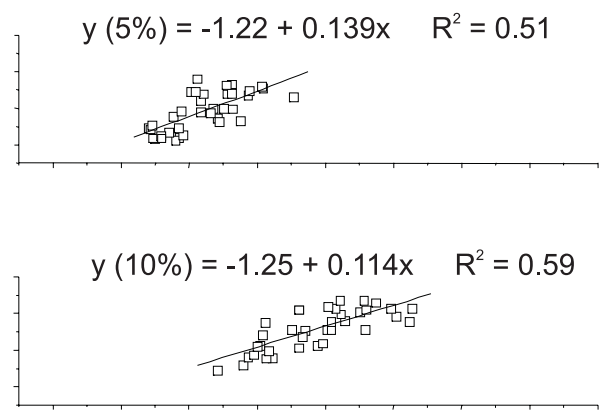

$y(15 \%)=-0.79+0.093 x \quad R^{2}=0.52$
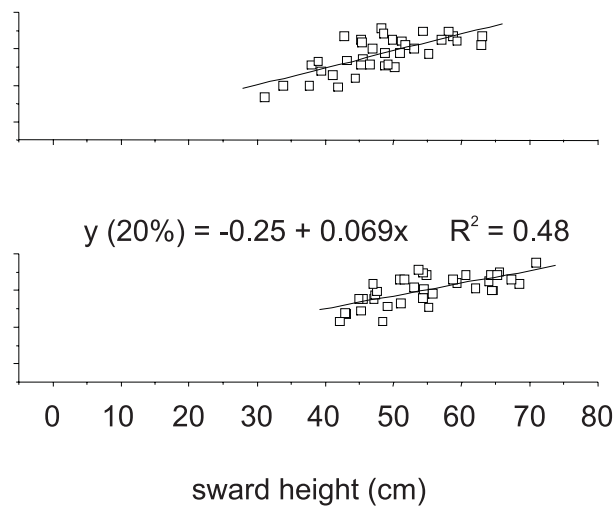

Figure 4 - Relationship between sward height and natural logarithms of the radiation fraction not intercepted (I/Io) in palisadegrass pastures under four HAL levels (\%, in parenthesis) in 2003 and 2004. Data include measurements taken pre- and postgraze, as well as on the $14^{\text {th }}$ day of regrowth.

completey supressed by grazing intensity, the slope $(b)$ changed from 0.065 (2003) to 0.139 (2004), probably due to increased tiller density population, a consequence of continued heavy grazing. In a companion study performed on the same pastures (Peternelli, 2003), mean tiller population densities at the end of the 2003 grazing season were $1,658,1,413,1,217$ and 1,087 tillers $\mathrm{m}^{-2}$ for 5, 10, 15 and 20\%-HAL. Under continuous stocking, both herbage production and utilization seem to be linked to a specific sward condition, such as LAI or LI, and in practice, these structural guidelines can often be "translated" to sward height (Parsons et al., 1983). Results of the present study, however, suggest that the relationship between LI and sward height can change over time, and that at least under intermittent defoliation regimens this association should be used with caution, as already pointed out by Parsons et al. (1988) and Busque \& Herrero (2001).

The increased pre- and postgraze HM and preand postgraze sward height during the course of the experiment resulted from the steady decrease in grazing intensity on the pastures under high HAL. In the first grazing cycle of 2003, HM disappearance (from intake and grazing losses) was $33,28,22$ and $20 \%$ for $5,10,15$ and 20\%-HAL, respectively. In the second grazing of the same year, HM diminished 29, 28, 17 and $13 \%$ for $5,10,15$ and $20 \%$-HAL, respectively. Therefore, the apparent decline in grazing intensity, comparing these two grazing cycles, was greater for 15 and 20\%-HALs. In perennial ryegrass (Lolium perenne cv. Belfort) pastures, the decrease of $\mathrm{HM}$ after grazing was 48,35 and $29 \%$ for 3, 5 and $8 \%$-HAL ( $8 \mathrm{~kg}$ DM per $100 \mathrm{~kg}$ live weight per day), respectively (Kim et al., 2001).

In addition to high HAL, the continuing reduction of the grazing intensity is thought to have been caused by the use of the rest period of 28-days, which proved too long for the conditions of the present study allowing for the accumulation of large amounts of stems leading to increased HM and sward height.

There was a HAL $\times$ period interaction $(P=$ $0.0025)$ for HAR in 2003, with a linear and positive effect of HAL in cycles I and II, but no effect of HAL on HAR in the third grazing cycle (Figure 5). In 2004, HAL did not affect $(P=0.1213)$ HAR, which was higher $(P$ $<0.0001)$ in the second $\left(75 \mathrm{~kg} \mathrm{DM} \mathrm{ha}^{-1}\right.$ day $\left.^{-1}\right)$ compared to first and third grazing cycles. Mean HAR was higher 
in 2003 than in 2004 ( 73 vs. $49 \mathrm{~kg} \mathrm{DM} \mathrm{ha}^{-1}$ day $^{-1}$ ), and was likely associated with lower mean temperatures during the 2004 grazing season (Figure 1). After the first two grazing cycles in 2003, when the effect of HAL on HAR was linear and positive, pasture response to HAL changed, as 10,15 , and $20 \%$-HALs caused a reduction in HAR in the third cycle, nulling out the effect of HAL on HAR. The high HAR in the first and second cycles of 2003 for the 10, 15, and $20 \%$ treatments was consistent with the taller swards in those pastures (Figure 3), as plant growth under those circumstances was mainly accounted for by intense stem development. In native pastures of Rio Grande do Sul, Brazil $\left(30^{\circ} \mathrm{S}\right)$, HAR increased linearly with the increase in HAL, due to the associated increase in LAI (Corrêa \& Maraschin, 1994). Conversely, however, high proportions of ungrazed stems and excessive

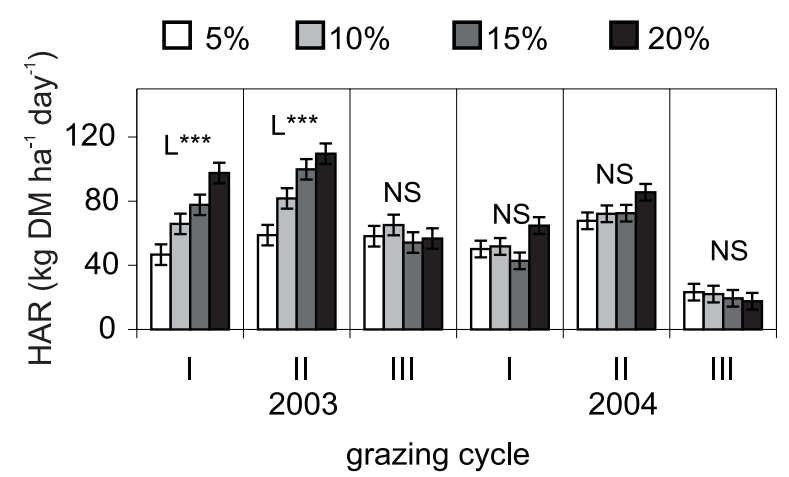

Figure 5 - Herbage accumulation rate (HAR) in pastures of palisadegrass during three periods in 2003 and 2004 in response to herbage allowance (HAL; 5, 10, 15, $20 \%$ ). Atop each HAL bar are mean standard error (MSE) bars (I). The orthogonal polynomial coefficients refer to HAL effect: L linear, Q quadratic effect, C cubic. $* * * P<0.001, * * P<0.01, * P<0.05$, NS not significant.

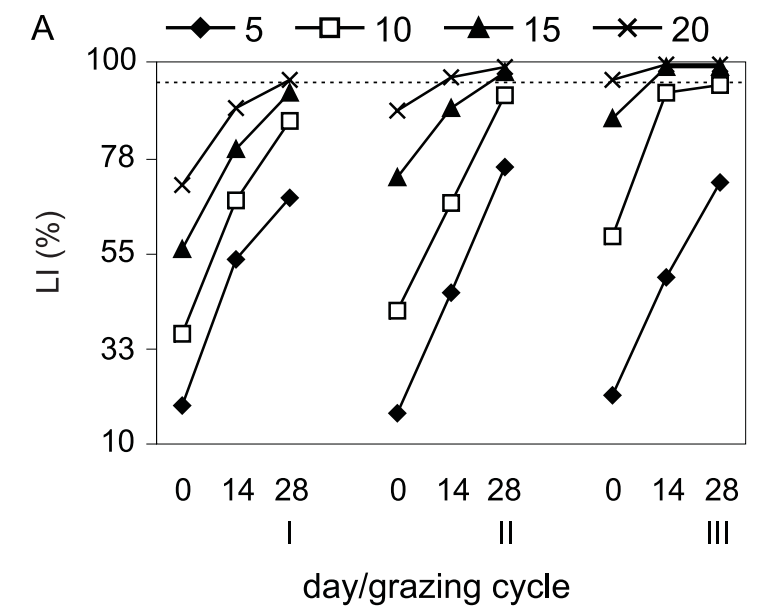

shading of basal tillers can reduce HAR, as reported by Adjei et al. (1980) for Cynodon spp. pastures. Consistent with the findings of the present study, Korte et al. (1984) reported that in mixed pastures of perennial ryegrass (Lolium perenne L.) and white clover (Trifolium repens L.), even though HAR was initially higher under lenient grazing, it decreased in subsequent grazings over the season.

Throughout the experiment, the decrease in HAR with increasing HAL was associated with high levels of LI (Figure 6), ultimately due to the decrease in grazing intensity. In the third grazing cycle of 2003, pastures under 15 and 20\% HAL approached $100 \%$ LI with only $14 \mathrm{~d}$ of regrowth. In 2004 there was a trend for increasing LI of swards kept under $5 \%$ HAL. Rather than a consequence of increased sward height and herbage mass (as was the case for the other HAL levels), high LI in the 5\%-HAL swards seems to be related to the predominance of more prostrate plants, a growth habit response induced by heavier grazing. Kim et al. (2001) evaluated the effect of HAL $(3,5$ and $8 \%$ ) on perennial ryegrass [Lolium perenne (L.) cv. Belfort] regrowth, and reported that only pastures under 3\% HAL responded with a decrease in HAR. The authors attributed this to intense leaf removal, and also to the low levels of organic reserves that resulted from the more severe defoliation. In the present study, HAR for $5 \%$-HAL remained constant during the course of the experiment, and seems to have responded only to weather conditions, especially at the end of 2004 .

Contrasting with the other three treatments, mean sward state of pastures under 5\% HAL remained fairly steady throughout the experiment, especially sward height. This combination of low HAL with the 28 -d rest period, though not devised as a sward con-

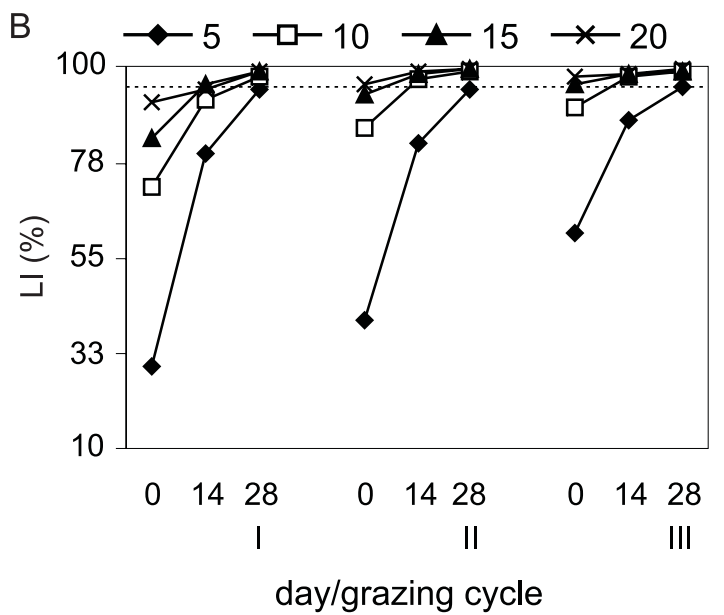

Figure 6 - Sward light interception (LI) during regrowth $(0,14$, and $28 \mathrm{~d}$ after grazing) in palisadegrass pastures during three grazing cycles in 2003 (A) and 2004 (B), in response to herbage allowance (HAL; 5, 10, 15, and 20\%). Dashed horizontal line at the top of the plot corresponds to $95 \%$ LI. 
trol tool, resulted in a narrow range of variation in sward conditions, in contrast with the three other HAL levels, where sward state was considerably more variable. This suggests that, if sward state control is a management goal under a fixed grazing schedule, the 5\%/ 28 -d rest combination may be a viable option, as grazing intensity in this situation was high enough to "buffer" the sward from significant alterations in structure over time. The reduction of HAR in pastures under 10, 15 and 20\%-HAL was associated with taller swards and higher HM during the course of the experiment, ultimately a consequence of underutilized forage. In pastures under 5\% HAL, HAR remained relatively constant as HM and sward height changed little. The LI response to sward height differed across HALs and between years, due to changes (increase) in tiller population density (Peternelli, 2003) and a more prostrate growth habit, ascertained by visual appraisal. The use of lax HAL levels (often used to increase individual animal performance) resulted detrimental to HAR and HAC. This negative effect was even more so under the grazing schedule employed, as the $28-\mathrm{d}$ rest period proved excessively long, leading to increased underutilization of the forage on offer. Under extreme circumstances, this could make for continued reduction in grazing intensity, and ultimately lead to less than maximal animal performance due to excessive lodging and low forage nutritive value.

The benefits of using a fixed defoliation schedule, as opposed to monitoring sward conditions and using them as grazing management guidelines, are obvious and relate to applicability and feasibility. On the other hand, the use of fixed rest periods often leads to incorrect timing of defoliation and underutilization of herbage produced, and may lead to deterioration of sward structure, forage nutritive value and pasture persistence. In addition, fixed rest periods and HALs (or stocking rates) make it difficult to predict and maintain postgraze stubble height, sward LI, and residual LAI and herbage mass, all key factors for regrowth. The manager must, therefore evaluate and understand the risks involved in each option, especially if management goals include minimal disturbance of the sward such as burning, mechanical harvesting of ungrazed forage, or other costly interventions in the system, especially at times when forage supply is high.

\section{ACKNOWLEDGEMENTS}

Thanks are due to FAPESP (Fundação de Amparo à Pesquisa do Estado de São Paulo), ESALQ (Escola Superior de Agricultura "Luiz de Queiroz"/ USP) and FZEA (Faculdade de Zootecnia e Engenharia de Alimentos/USP) for the provision of a graduate scholarship to the first author and research funds for this project.

\section{REFERENCES}

ALMEIDA, E.X.; MARASCHIN, G.E.; HARTHMANN, O.E.L.; RIBEIRO FILHO, H.M.N.; SETELICH, E.A. Oferta de forragem de capim-Elefante Anão Mott e a dinâmica da pastagem. Revista Brasileira de Zootecnia, v.29, p.1281-1287, 2000.

ADJEI, M.B.; MISLEVY, P.; WARD, C.Y. Response of tropical grasses to stocking rate. Agronomy Journal, v.72, p.863-868, 1980.

BOVAL, M.; CRUZ, P.; PEYRAUD, J.L.; PENNING, P.D. The effect of herbage allowance on daily intake by Creole heifers tethered on natural Dichanthium spp. pasture. Grass and Forage Science, v.55, p.201-208, 2000 .

BUSQUE, J.; HERRERO, M. Sward structure and patterns of defoliation of signal grass (Brachiaria decumbens) pastures under different cattle grazing intensities. Tropical Grasslands, v.25, p.193-204, 2001.

CÔRREA, F.L.; MARASCHIN, G.E. Crescimento e desaparecimento de uma pastagem nativa sob diferentes níveis de oferta de forragem. Pesquisa Agropecuária Brasileira, v.29, p.1617-1623, 1994.

FORAGE AND GRASSLAND TERMINOLOGY COMMITTEE FGTC. Terminology for grazing lands and grazing animals. Journal of Production Agriculture v.5, p.191-201, 1992

HUMPHREYS, L.R. Tropical pasture utilisation. Cambridge: Cambridge University Press, 1991. 206p.

KIM, T.H.; AN, K.W.; JUNG, W.J. Effects of daily herbage allowance on the organic reserves at the end of grazing and the accumulation of herbage during regrowth. Australian Journal of Agricultural Research, v.52, p.883-890, 2001.

KORTE, C.J.; WATKIN, B.R.; HARRIS, W. Use of residual leaf area index and light interception as criteria for spring-grazing management of a ryegrass-dominant pasture. New Zealand Journal of Agricultural Research, v.25, p.309-319, 1982.

KORTE, C.J.; WATKIN, B.R.; HARRIS, W. Effects of timing and intensity of spring grazings on reproductive development, tillering, and herbage production of perennial ryegrass dominant pasture. New Zealand Journal of Agricultural Research, v.27, p.135-149, 1984.

LEMAIRE, G. Ecophysiology of grasslands: Dynamic aspects of forage plant populations in grazed swards. In: INTERNATIONAL GRASSLAND CONGRESS, 19., São Pedro, 2001. Proceedings. Piracicaba: FEALQ, 2001. p.29-37.

LITTELL, R.C.; MILLIKEN, G.A.; STROUP, W.W.; WOLFINGER, R.D. SAS system for mixed models. Cary: SAS Institute, 1996. $633 \mathrm{p}$.

MACEDO, M.C.M. Análise comparativa de recomendações de adubação em pastagens. In: SIMPÓSIO SOBRE MANEJO DA PASTAGEM, 21., Piracicaba, 2004. Anais. Piracicaba: FEALQ, 2004. p.317-356.

McCARTOR, M.M.; ROUQUETTE Jr., F.M. Grazing pressures and animal performance from Pearl Millet. Agronomy Journal, v.69, p.983-987, 1977.

MELLO, A.C.L.; PEDREIRA, C.G.S. Respostas morfológicas do Capim-Tanzânia (Panicum maximum Jacq. cv. Tanzânia-1) irrigado à intensidade de desfolha sob lotação rotacionada. Revista Brasileira de Zootecnia, v.33, p.282-289, 2004.

NUNES, S.G.; BOOCK, A.; PENTEADO, M.I.O.; GOMES, D.T. Brachiaria brizantha cv. Marandu. Campo Grande: EMBRAPACNPGC, 1984. 31p. (Documentos, 21).

PARSONS, A.J.; LEAFE, E.L.; COLlET, B.; STILES, W. The physiology of grass production under grazing. I. Characteristics of leaf and canopy photosynthesis of continuously-grazed swards. Journal of Applied Ecology, v.20, p.117-126, 1983.

PARSONS, A.J.; JOHNSON, I.R.; HARVEY, A. Use of a model to optimize the interactions between frequency and severity of intermittent defoliation and to provide a fundamental comparison of the continuous and intermittent defoliation of grass. Grass and Forage Science, v.43, p.49-59, 1988. 
PEDREIRA, C.G.S.; ROSSETO, F.A.A.; SILVA, S.C.; NUSSIO, L.G.; MORENO, L.S.B.; LIMA, M.L.P.; LEME, P.R. Forage yield and grazing efficiency on rotationally stocked pastures of 'Tanzania-1' guineagrass and 'Guaçu' elephantgrass. Scientia Agricola, v.62, p.433-439, 2005.

PETERNELLI, M. Características morfogênicas e estruturais do capimBraquiarão [Brachiaria brizantha (Hochst ex A. Rich.) Stapf. cv. Marandu) sob intensidades de pastejo. Pirassununga: USP/FZEA, 2003. 79p. (Dissertação).

SANTOS, M.V.F.; DUBEUX JR., J.C.B.; SILVA, M.C.; SANTOS, S.F.; FERREIRA, L.C.; MELLO, A.C.L.; FARIAS, I.; FREITAS, E.V. Produtividade e composição química de gramíneas tropicais na Zona da Mata de Pernambuco. Revista Brasileira de Zootecnia, v.32, p.821-827, 2003.

SAS INSTITUTE INC. SAS/STAT User's Guide, Version 7-1. Cary: SAS Institute Inc., 1999. 325p.

SOLLENBERGER, L.E.; MOORE, J.E.; ALLEN, V.G.; PEDREIRA, C.G.S. Reporting herbage allowance in grazing experiments. Crop Science, v.45, p.896-900, 2005.

TEIXEIRA, E.I.; MATTOS, W.R.S.; CAMARGO, A.C.; ROSSETO, F.A.A.; TEIXEIRA, C.S.P. Avaliação de produção e utilização de uma pastagem de capim Tobiatã (Panicum maximum cv. Tobiatã) sob pastejo rotacionado. Scientia Agricola, v.56, p.349-355, 1999.
VALLE, C.B.; JANK, L.; RESENDE, R.M.S.; CANÇADO, L.J. O papel da biotecnologia de forrageiras para a produção animal. In: REUNIÃO ANUAL DA SOCIEDADE BRASILEIRA DE ZOOTECNIA, 41., Campo Grande, 2004. Anais. Campo Grande: SBZ, 2004. 1 CD-ROM.

VILELA, L.; MARTHA JR., G.B.; BARIONI, L.G.; BARCELLOS, A.O. Adubação na recuperação e na intensificação da produção animal em pastagens. In: SIMPÓSIO SOBRE MANEJO DA PASTAGEM, 21., Piracicaba, 2004. Anais. Piracicaba: FEALQ, 2004. p.425-472.

VIRKAJÄRVI, P.; SAIRANEN, A.; NOUSIAINEN, J.I.; KHALILI, H. Effect of herbage allowance on pasture utilization, regrowth and milk yield of dairy cows in early, mid and late season. Animal Feed Science and Technology, v.97, p.23-40, 2002.

Received January 02, 2006

Accepted March 20, 2006 